\title{
Evlenme Geleneğine Müzik Davranışları Açısından Bakış: Gelin Ağlatma-Alma-İndirme Havaları Örneği
}

"Düğ̈̈nsüz köy, şakırdaksız değirmene benzer"

Eray ALPYILDIZ*

\begin{abstract}
$\ddot{O} \mathbf{z}$
Geçiş dönemleri ile müzik ilişkisi pek çok açıdan irdelenebilecek konulardandır. Müziğin bir ritüel olarak en yaygın olarak kullanıldığı ve işlev gördüğü geçiş dönemi “evlenme”dir. Evlenmenin toplumsal ilanı ve kutlaması olan düğünler, müzik ile iç içe geçmiş ve müzikle ifade edilegelen geleneksel eğlenceler/törenler/kutlamalardır. Düğün törenleri içerisinde müzik, duyurma, eğlenme, eğlendirme, oynatma gibi açık işlevlere sahip olmanın ötesindedir. Evlenme geçiş döneminin her aşaması ayrı bir müzikal karaktere sahip olacak şekilde kültürel kodlamalar ve işlevler doğrultusunda ezgisel yapı ve içerik kazanmaktadır. Bu dönemde kültürel olaylar dizisi, müziği oluşturmakla birlikte müzik de yeni davranışları yaratmaktadır. Başka bir açıdan ifade ettiğimizde müziğin icra edilebilmesi, söz konusu kültüre özgü öğrenilmiş davranışlar dizisi olmasının yanı sıra müziği anlama ve anlamlandırma da bu kapsam içerisine girmektedir. Bu açıdan bir kültür içerisinde müziği icra eden çalgıcının doğru ve anlamlı performans ölçüsü, bağlama özgü tavır takınmakla ortaya konulabilmekte; bununla beraber müziğin yansıtıldığı kitlenin ezgisel yapıyı anlama/anlamlandırma yeteneği ve bu doğrultuda gerçekleştirecekleri her türlü davranış da geleneğe ilişkin kalıp yargıları önceden öğrenmeye bağlı olmaktadır.

Bu bağlamda makalede "müzik ile kültür ekseninde" gelenek müziğinin evlilik geçiş dönemi ile ilişkisi, bağlamsal şartlar çerçevesinde incelenmiş; müziğin, bir kültür içerisinde davranış biçimi olarak nasıl konumlandığı, kodlandığı ve yansıtıldığına ilişkin çözümlemeler yapılmıştır.
\end{abstract}

Anahtar kelimeler: Müzikal Davranış, Geçiş Dönemi, Evlilik, Düğün, Kına Gecesi.

\section{A Look at the Transition Period of Marriage in Terms of Music Behaviors: The Gelin Ağlatma-Alma-İndirme Melodies}

\begin{abstract}
The relationship between transition periods and music is one of the topics that can be examined in many respects. Marriage is transition period in which music is most commonly used and function as a ritual. Weddings, which are social proclamation and celebrations of marriage, are traditional entertainments / ceremonies / celebrations intertwined with music and expressed by music. Each stage of the marriage transition period has a distinctive musical character which melodic structure and content in line with cultural codes and functions. In this period, cultural events series, also creates new behaviors as well as creating music. In other words, take shape the performance of musicial and create music depends on the culturel specific sequence of learned behaviors as well as the ability to understand and make sense of music. Therefore music is a system which have of indicators specific to culture and is based on meaning. In this context, in this article, the relationship between tradition music and marriage transition period is examined within the context of contextual conditions in addition to how music is positioned, coded and reflected as a behavior in a culture.
\end{abstract}

Keywords: Musical Behavior, Transition Period, Marriage, Wedding, Henna Night.

Received/Geliş: 20.02.2020

Accepted/Kabul: 14.05.2020

* Bu çalışma, insanlardan veri ve örnek toplamayı gerektiren, anket, inceleme, alan çalışması ve deney içeren araştırmalar 'kapsamına girmediğinden etik kurul onay belgesi gerektirmemektedir.

* Doktora Öğrencisi, Hacettepe Üniversitesi Türk Halkbilimi Bölümü, erayalpyildiz@ gmail.com, (D/0000-0002-89674612

(Makale türü: Araştırma makalesi) 


\section{Giriş}

Geçiş dönemleri, halkbiliminin çalışma kadrosu içerisinde halk inançları, halk ekonomisi, halk mutfağ1 (yemek kültürü), mizah/eğlence, giyim-kuşam, halk oyunları/dansları, halk edebiyatı gibi başlıklar altında incelenebilen ve çeşitli ritüellerle uygulanagelen yaşamsal aşamalardır. Halk tarafından beşik-eşik-keşik üçlemesiyle adlandırılan bu dönemler, yaşamsal döngünün sacayaklarıdır. Doğum, evlenme ve ölüm evrelerinde, literatürdeki adıyla geçiş dönemlerinde, zengin ritüellerin uygulanması hayatı anlama, anlamlandırma ve anlatma çabalarının gelenek kültürü çerçevesinde ifade ediliş biçimleridir. Geçiş dönemi içerisinde yer bulan ritüellerden biri ise müziktir. Müzik, bir iletişim biçimi olarak geçiş dönemine ezgisel bir anlam katma işlevine sahiptir. Çalışmamıza konu olan evlilik geçiş dönemi ise müzik ile ilişkinin -başlangıcından sonuca kadar- en yoğun ve fazla olduğu evredir. Evliliğin kutlaması ve ilanı olan düğünlerde icra edilen müziğin duyurma, eğlendirme, oynatma, ağlatma gibi temel işlevleri bulunmaktadir.

$\mathrm{Bu}$ bağlamda müzik, kültürel kodlarla oluşan davranış biçimlerinin ezgisel ifadesidir. Başka bir deyişle kültür, davranışları belirlemektedir. Kültürün biçimlediği davranış ise kendisini müzik şeklinde göstermekte/anlatmakta/ifade etmektedir. Bununla beraber yaratılan müzikten hareketle tekrar davranış biçimleri ortaya çıkmakta ve kültür içerisinde bağlamsal şartlara özgü nasıl bir tavır takınılacağı da müziğin iletişim kanalıyla belirlenmektedir.

$\mathrm{Bu}$ çalışmada bir davranış biçimi olarak kabul edilen müziğin, evlilik geçiş dönemi törenlerinden dügünlere yansıması incelenmiş; müziğin kullanım şekilleri, ifade ettiği anlam ve ortaya çıkan anlamdan tekrar ne tür bir davranma biçimi oluştuğu/geliştiği sorgulanmıştır.

\section{Bir Davranış Biçimi Olarak Müzik}

Alan Marriam’a (1964) göre etnomüzikoloji müzikte yalnız sesi değil, ses üretebilmenin ön şartı olan insan davranışını da içerir. Müzik, insanların kontrolü ve davranışı dışında bir düzeyde var olamaz ve çeşitli davranışlar söz konusudur (s. 14). "Müzik, tek başına bir ses olgusu olarak tanımlanamaz, çünkü bireylerin ve birey gruplarının davranışlarını içerir ve özel organizasyonu, ne olabileceğine ve olamayacağına karar veren insanların sosyal uyumunu gerektirir" (Marriam, 1964, s.27-28).

Bu konuda bir noktaya dikkat çeken Merriam, "müzikle ilgili kavramlar olmadan davranış gerçekleşemez ve davranış olmadan müzik sesi üretilemez" görüşünde bulunmuştur. Bununla beraber kültürel değerlerle anlam kazanan kavramların tek başına müzik üretemeyeceğine ve kültürel olarak kabul edilebilir müzik sesine yol açan çeşitli davranışlara çevrilmeleri gerektiğine işaret etmiştir (Merriam, 1964, s. 33).

Bu bağlamda Merriam, (1964) sesin üretilmesi ve düzenlenmesi konusunda dört davranış türü belirlemiştir. Bunlar "fiziksel davranış", müzik sesi ile ilgili "sözlü davranış”, hem müzik 
yapanların hem de dinleyen ve yanıtlayanların "sosyal davranışları" ve müzisyenin uygun sesleri üretmesini sağlayan “öğrenme davranışı”dır (s. 103).

\section{Bir Geçiş Dönemi Olarak "Evlenme" ile "Müzik" İlişkisi}

"Toplumun geleceğinin en önemli ve belirleyici yapı taşlarından biri olan aile kurumunun meydana gelmesindeki ilk basamak kabul edilen evlilik, kız ve oğlanın evlenme isteğini belirtmelerinden gerdek sonrasına kadar devam eden her safhasında göstergebilimin renkli ve çeşitli örnekleriyle zengin bir tablo halinde karşımıza çıkmaktadır (...) Evlenme geleneğinde uygulanan ritlerin hepsinin ortak amac1, evlenenlere, dolayısıyla yeni kurulan aileye saadet, bolluk, bereket, refah getirmek; soyun sürmesini sağlamak; aynı zamanda, her türlü olumsuzluk ve kötülüklerden korumaktır" (Eker, 2000, s. 93, 99).

Hayatın bu önemli geçiş döneminin toplumsal ilanı, kabulü ve kutlaması olan düğünler, düğün öncesi, düğün sırası ve düğün sonrası olmak üzere üç aşamadan meydana gelmektedir. Dügünün her evresinde müzik, kültürel bir davranış şekli olarak olayı/olayları karakterize etmektedir. Merriam, "birlikte alındıklarında toplumda müziğin hangi sırayla düzenleneceği ve hangi müziğin ne olması gerektiği hakkında düşünecekleri insanlar oluşturur” (s. 63) demektedir. $\mathrm{Bu}$ doğrultuda "düğün melodilerinin oluşma aralığı, bir düğüne eşlik eden tüm hareketleri içerir" (Elschekova, 1997, s. 43). A. Elschekova göre, “düğünün evrelerinin çoğu belirli vokal ve kurumsal biçimlere bağlıdır ve bu nedenle müzik malzemesi oldukça geniştir (...) Şarkılar, yeni bir aile topluluğuna kabul karşılamasının yanı sıra ebeveynlerin evine ve ailesine veda töreninin müzikal karakteristiğidir. Şarkıların karakteristik unsurları ve işlevleri, bu ayrılık ve kabul törenlerine karşılık gelir” (s. 41). Bu bağlamda Elschekova (1997) düğün şarkılarını -işlevlerinden hareketle- "yas şarkıları, kutlama şarkıları, dans ve şaka şarkıları" şeklinde üç tür olarak sinıflandırmıştır (s. 42).

Müzik, düğünün başlangıcından sonuna kadar duyurma, eğlendirme, oynatma, ağlatma gibi açık işlevlerde bulunmasına karşılık; olay örgülerinden hareketle anlam kazanan kapalı işlevleriyle düşünülmelidir. Ezginin yapısı, çalgının türü ve müzik dağarcığının belirlenmesinde gelenek içerisindeki kültürel aşamalar etkili olmaktadır. Bu açıdan düğün içerisinde müzik, bir kültürün davranış biçimleri olarak sunulmaktadır.

\section{Müziğin Bir Davranış Olarak Düğünlere Yansıması}

Düğün öncesi uygulamalar içerisinde müziğin yer bulduğu ilk örnek nişan törenidir. Genellikle tanışma, kaynaşma, ziyaretleşme ve hediyeleşme ritüelleriyle gerçekleşen nişan törenlerinde müzik, eğlenme, oynama ve oynatma aracı olarak icra edilir. Düğünün başladığının sembolik ilanı olan bayrak asma geleneği ise müziğin bir davranış olarak kendisini gösterdiği önemli bir ritüeldir. Evlilik geçiş dönemi, -bu çalışmada çözümleneceği gibi -birçok yönüyle savaş ritüellerine benzemektedir. Halk dilinde yuva kurmak şeklinde ifade edilen evlenme, düğün 
evine çekilen bayrakla yeni bir devlet kurulmuşçasına sembolize edilir. Bayrağın dikilişi sırasında davul ve zurna çalgılarıyla müzik icra edilmesi, bu olayın sembolik davranışını yansıtmaktadır. Bu noktada müzik sesi ile sembolleştirme yapılmaktadır.

Dügün sırası ritüeller içerisinde önemli bir aşama olan kına gecesi törenleri ile müzik ilişkisi ağıt ritüeli şeklinde kurulmaktadır. "Düğün töreninin temeli kabul edilen coşku ve eğlencenin adeta ağıt havasına dönüştüğü bölüm olan kına” (Eker, 1998, s. 199) geçiş dönemleriyle ilgili eğlenceler içerisinde sevincin hüzün ile yer değiştirdiği bir yapıdadır. Yeni bir aile kurmanın verdiği heyecan ve heves ile söylenilen eğlendirme işlevli türküler, törenin bir yerinde kesilerek gelinin baba evinden ayrılığının sembolleştirildiği bir içeriğe bürünür. Geline kına yakıldığı sırada gerçekleştirilen birtakım işlemlerle söylenilen bu türkülere gelin ağıtı veya gelin yası denilir. "Kına ağıtı, gelin ağlatma havası, ağıt havası, gelin türküsü, gelin yası, okşama, gelin savusu gibi adlarla da bilinen bu folklorik ürünler konu itibariyle ağıt türündedir” (Görkem, 2001, s. 18). Bu kültürel yapının psikososyal dışavurumu ise ağlamaktır. Ancak buradaki duygusal tepkimeler bir statüden başka bir statüye geçişin izdüşümleri şeklindedir ve öznenin yaşamına devam etmesi söz konusudur. Pertev Naili Boratav'ın belirttiği gibi (1982) “bunlara vesile olan olaylarda ölüm acısı niteliğinde bir yön yoktur. Yalnız iki vesilede, ölüm ve evlenme hallerinde, ağıt bir tören öğesi olur" (s. 444).

Evlenme geçiş döneminin bir aşaması olan kına törenlerinde ağlama eylemi, yuvaya bolluk/bereket ve uğur getireceği inancıyla önemli bir ritüel olarak icra edilir. "Ağlaya ağlaya eken, güle güle biçer” (Ataman, 1992, s. 32) şeklindeki atasözü bu kültürel yapının bir ifadesi olarak karşımıza çıkar. Gelenek kültürü içerisinde teması ayrılık, konusu gelinin baba evinden ayrılırken yaşadığı hüzün olan kına gecesinde/töreninde, ağlamaktan ziyade ağlatmak amaçtır. Gelinin fizyolojik bir davranışına dönüşen ağlamak bir sonuçtur ve bunu sağlamanın aracı ise müzik olmaktadır. Bu doğrultuda kına gecelerinde gelini ağlatmak için söylenilen ezgilere "gelin ağlatma havası" denilmesi dikkate değerdir. Hava sözcüğünün karş1lığının müzik/ezgi olması, müziğin bu acıklı olayın bir davranışı olarak kullanıldığını göstermektedir. Diğer taraftan geleneksel kına gecesinde müzik, düğün töreni içerisinde enstrüman yönüyle zengin olmayan bir yapıdadır. İcracılar, genellikle profesyonel müzisyenlerden ziyade toplumda söz sahibi olan, geleneği sürdürme birikimine sahip orta yaş üzeri kadınlardır. Kına gecelerinde genellikle ritim sazlardan tef çalgısı eşliğinde kadınlar tarafindan türküler söylenmektedir. Bu bağlamda gelenek kültürü içerisindeki kına gecelerinde müzik, Alan P. Merriam'ın nitelendirmesiyle "sözlü bir davranış" (verbal behavior) şeklinde gerçekleştirilmektedir. Merriam’a göre bu, "müzik sesi ile ilgili ne kullanılırsa kullanılsın sözlü davranıştır. Bu da elbette altta yatan müzik kavramlarının bir yansımasıdır, ancak bu durumda özellikle insanların müzik yapısı ve onu çevreleyen kriterler hakkında söylediklerine uygulanır" (s. 114). 
Türk halk müziği repertuarı içerisinde "Atladı çıktı eşiği/Sofrada kaldı kaşığı; Çattılar ocak taşını/ Kurdular düğün aşını/Çağrın gelsin kardaşını; Altın tas içinde kınam ezdiler/Gümüş tarak ile zülfüm çözdüler/Yatsıya varmadan başım bozdular; Gelin ağlar yaşın yaşın/ Gitmem diye sallar başın” gibi kına türkülerinde görülebileceği üzere, müzik sözlü bir davranış olarak ayrılık/gurbet temasının kişi ve grup belleğine çağrılmasıyla icra edilmektedir.

Günümüzde kına gecesi törenlerinde ise ağıt ritüeli, sosyo-kültürel değişim ve dönüşümlere paralel olarak gelenek kültürünün yoğun yapısından sıyrılarak yeni içeriklerle ve işlevlerle sürdürülmektedir. Geleneksel kına gecesi "kent yaşamı kökenli eğlenceler kapsamında" (Özdemir, 2005, s. 64) kültürel bir niteliğe bürünmekte ve bekârlığa veda partisi gibi kent kökenli popüler eğlence kültürünün bir öğesi şeklinde de işlev görmektedir. Bu doğrultuda çağın getirdiği yeni kültürel ekonomik içeriklerle giyim-kuşam, müzik, yemek, sosyal çevre, mekan kimliğinde dönüşümler yaşanmaktadır.

\subsection{Gelin Alma-Göçürme, İndirme Havaları Ekseninde Şekillenen Müzikal Davranışlar}

Düğün töreninin sonraki aşaması olan ve gelin kızın baba evinden koca evine götürülme olayına gelin alma/gelin göçü/gelin göçürme denilmektedir. Bu gelenek, oğlan evinden yola çıan ve adına gelin alayı denilen bir kafilenin seferidir. Gelinin bindirileceği atın süslenmesi ve bir dizi hazırlıkla başlayan yola çıkışa davul zurna eşlik etmektir. Aynı zamanda duyurma/ilan etme işlevi taşıyan müzik eşliğindeki bu uygulamaya yol boyunca danslar/oyunlar da katılmaktadır. Bayrak asma ritüelinden başlayarak gelinin oğlan evine getirilişine kadarki gelin alma (göçürme), gelin indirme, gelin karşılama uygulamaları bir yönüyle savaş/fetih göstergeleridir. Dügüunlerde gelin, sembolik olarak fethedilecek ülkenin sınırlarını genişletecek toprak gibi kutsanmakta, karşılanmakta ve başarının ardından da olay kutlanmaktadır. Düğün geleneği içerisinde gelini almak için kız evinin önüne gelen gelin alayı, kendi atmosferleri dışında bir yapıyla karşılaşır. Bu noktada "klz evi yasta, oğlan evi pek havasta”dir. Düğünün yasa dönüştüğü ve veda töreninin gerçekleştirildiği kız evindeki dramatik olaya saygı duyulur. Müzik ise bu durumun davranışı olarak yerini ağır havalara teslim eder. Gelenek içerisinde gerçekleşen bir müzikal davranış olarak bunun adı "gelin alma/gelin göçürme havalarl"dır. Genellikle sözsüz olan ve enstrümantal icra tercih edilen bu ezgilerde ritim saz olarak davul, üflemeli saz olarak da zurna veya klarnet çalgısı kullanılmaktadır.

Bu bağlamda ortaya çıkan müzikal davranış şekillerini (fiziksel davranış, sosyal davranış, ögrenme davranışı, sembolik davranış) şöyle çözümleyebiliriz:

Merriam’a göre (1964) “bu davranış şekillerinden birincisi, fiilen ses üretimine dahil olan, sesin üretilmesinde bedenin fiziksel gerilimine ve duruşuna ve bireysel organizmanın sese olan fiziksel tepkisine ayrılabilen fiziksel davranıştır. "Fiziksel davranış, sesin üretilebilmesi için 
-ses bir müzik aleti üzerinde üretilecekse- insanların parmaklarını esnetmesi, dudaklarını ve diyaframını kullanması ya da ses vokal ise ses tellerini ve diyaframı manipüle etmesi gerektiği gerçeğini ifade eder" (s. 32, 103). Fiziksel davranış olarak bu seslendiriliş stili "gerçekleşen icrada söylenen türkünün kendisine ait özelliklerin yanı sıra, onun nasıl söylendiği, icracının duruşu, oturuşu, icranın koro veya solo oluşu, kadın, erkek veya karma söylenişi, ezgiye dans eşliğinin olup olmaması gibi hususlarını" (Mirzaoğlu, 2015, s. 13) kapsamaktadır. Alan Lomax tarafından "bir dizi davranış bütününün bir fonksiyonu" olarak tanımlanan ve "mevcut kültürel karakterin bir portresini veren türkü icra stili, bir kültüre mensup üyelerin ses davranışlarını belirli bir modele uydurdukları bir anlaşma, ittifak unsurudur" (Lomax, 1968'den aktaran Mirzaoğlu, 2015, s. 25).

Gelin alma/çıkarma/göçürme havalarında -diğer bağlamsal şartların yanında- durumsal bağlam (situational context) göz önünde bulundurularak icra edilen müzik davranışı söz konusudur. "Kültürel olarak dizayn edilmiş ve tanımlanmış davranış, tecrübe" şeklinde iletişimsel bir olayın analizine dayanan durumsal bağlamda "kültürel zemin icrayı karş1lıklı iletişim ve etkileşim değerleri ve hareketlerin sıralanışına göre yönetir" (Çobanoğlu, 2005, s. 217). Bu doğrultuda evin içerisine yas havasının yerleştiği ve veda töreninin gerçekleştirildiğinin bilindiği bir ortamın müziğinin fiziksel bir davranış olarak nasıl yansıyacağını bağlamsal şartlar belirlemektedir. Enstrüman aracılığıyla üretilen sesin zaman içindeki akışı yavaşlamakta, vuruşlar da buna bağlı şekillenmektedir. Fiziksel bir davranış olarak müzik, sesin üretilme aşamasından başlayarak ritmi düşürmekte, hareketleri yavaşlatmakta, durdurmakta ya da bağlamsal şarta göre hız kazandırmaktadır. Bununla beraber "bedensel tavır ve duruşlarla da temsil edilen fiziksel davranış" (Marriam, 1964, s. 32, 14) müzisyende bu hüzünlü törene uyum sağlayacak şekilde yansımaktadır. Örneğin davulcunun bahşiş almak için düğün sahibi/kahyası veya herhangi bir düğün misafirinin önünü keserek tokmağıyla anlam yarattı̆̆ı fiziksel davranış henüz görülmemekte; başka deyişle bağlamını (sırasını) beklemektedir. Müziğin kültürden hareketle fiziksel bir davranış olarak ortaya çıkmasıyla beraber, üretilen veya icra edilen müziğin topluluğun fiziksel davranışlarına yansıdığı gözlenmektedir. Grubun fiziksel davranışında "karakteristik bedensel tavırlar, duruşlar ve gerginlikler gözükmekte" (Marriam, 1964, s. 32, 108) ve hareketler daha sabitleşmektedir.

Müziğin fiziksel bir davranış olarak yansıdığı diğer bir örnek ise çalg1 seçimidir. Düğünlerde davul ve zurnanın kullanılması müzik aleti üzerinde üretilecek sesin geniş alanlara duyurulabilmesi kadar insanların fiziksel tepkilerinin yönlendirilmesinde etkilidir. Tarih sahnesinde görüldüğünden beri "kötü ruhu kovmak, dansa eşlik etmek, düşmanı ya da av1 korkutmak, haberleşmek, duyuru, kutlama" (Çelik, 2017, s. 12) gibi amaçlarla çeşitli ritüellerin önemli bir figürü olan davul, sadece ritim duygusundan doğmuş bir alet değildir. Bu bağlamda 
dügünler içerisinde fiziksel bir davranış olarak kişileri/grupları yönlendirme [oynatma, yürütme, oturtma, kaldırma] gücü ve işlevine sahiptir.

Diğer taraftan müzik ile sembol ilişkisi içerisinde bir çalgının türü, şekli, ses rengi ve icra bağlamı bir kültürde o çalgıya sembolik anlamlar kazandıran faktörlerdir. Bu sembolik anlamlar cinsel göndermeler, toplumsal cinsiyetle özdeşlemeler, dinsel-mezhepsel çıkarımlar gibi özelliklerle çeşitlenmektedir. Davul ve zurna ise tür, şekil, ses rengi, icra bağlamı açısından bir yerde dügün olduğunun/yapıldığının sembolüdür. "Düğünde davul zurna, hamamda kurna" (Ataman, 1992, s. 48) şeklinde atasözü de bu gereklilik ve sembolleştirme çerçevesinde söylenmiştir.

Gelin alma/çıkarma/göçürme havaları adıyla icra edilen müzik, kültürün duygusal arka planından çıkış almaktadır. Merriam'ın (1964) deyişiyle müzik, burada “insan davranışını sembolize etmektedir" (s.253). Bu noktada gelinin baba evinden ayrilırken ortaya konan belirli ritüellerden biri olan müzik, bir davranış olarak ayrılığı sembolleştirmektedir. Bu bağlamda müzikle yansıtılan melodik bütünlük ve içerikle anlam ifade edebilme kadar, neden-sonuç ilişkisi içinde olay karşısında konumlanıp anlamlı gürültüler çıkarmak da müziğin sembolik bir davranış olduğunun göstergesidir. Başka bir deyişle müzik "gürültünün düzenlenmişi, evcilleştirilmişi, törenleştirilmişidir” (Attali, 2014, s. 24).

Müziğin başka bir davranış türü olarak ortaya çıkan şekli "müzisyenlerin toplumsal rolü, profesyonel olup olmaması, toplum yapısına göre uygun davranması gereken eylemleri" çerçevesinde yorumlanan "sosyal davranış"tır. Merriam (1964) profesyonelliğin, "müzik mesleğine tam bağl1lı ve müzikten toplam ekonomik gelir elde etme anlamına geldiğini varsayarak herhangi bir toplumda gerçekten profesyonel olarak adlandırılabilecek çok az kişi olacaktır. Öyleyse, tüm müzisyenler uzmandır ve bazı müzisyenler profesyoneldir, ancak profesyonellik derecesi değişebilir" (s. 125) görüşünde bulunmuştur. Bu durum, kına gecelerinde profesyonel olmayan ama kültür uzmanı olarak türkü söyleyen kadınlar örneğinde görülebilir. Bununla beraber "gelin alma havalarında" da görüleceği üzere toplumsal kabul gören müzisyenin sosyal davranışı ondan beklenileni verme veya bağlama özgü tavır takınma biçiminde gerçekleşmektedir. Bu noktada müzisyen, gelin alma havaları adıyla çaldığı ezginin genel yapısına empati, sayg1, ciddiyet, istek, ikna duygularını katmaktadır. Yani Attali’ye göre "müzisyen de müzik gibi hep ikili oynar. Hem musicus hem cantor, yani üretici ve peygamber olur. Dışlandığg zaman dünyaya tenkitçi gözle bakar. Kabul edildiğinde ise tarihçi ve en büyük değerlerin yankısı oluverir” (Attali, 2014, s. 19).

Müziğin ifade edildiği "öğrenme davranışı" ise kültürün bir bütün olarak öğrenilmiş davranış olduğu anlayışından hareketle "yalnızca bir ünite olarak kabul edilen müzik davranışının öğrenilmesi gerektiği anlamında değil, aynı zamanda müzik yapma sürecini dinamik ve sürekli 
değişen kılan bağlantıyı oluşturduğu" (Marriam, 1964, s. 145) için önemli görülmüştür. Bu bağlamda müzisyenin dağarcığının oluşması kadar bu dağarcığı kültürel yapıya özgü icra (çalış/söyleyiş̧) stiliyle yansıtması; bu stili de düğün töreni içerisinde değişiklik/çeşitlilik gösteren yapılara özgü kullanması esas olmaktadır. Yani gelin alayıyla beraber kız evinin kapısına dayanan müzisyenin bu bağlamda icra edeceği dramatik karakterli müzik ile gelin indirmeden sonra eğlence/eğlenme/eğlendirme amaçlı dansların müziği farklıdır. Müzisyen bu noktada, öğrenilmiş bir davranış olarak farklı yapıda müzik icra ettiği gibi düğün geleneği içerisinde değiş̧iklik gösteren evreleri birleştirmektedir. Yine bu doğrultuda müziğin öğrenilmiş bir davranış olarak müzisyen üzerindeki etkisinin diğer bir işlevi de kültürü öğrenmesidir. Diğer bir ifadeyle müzik bilgisinin oluşması, ezgi dağarcığının genişlemesi, icra stilinin kazanılması, icra içeriğinin bağlama özgü belirlenmesi öğrenilen kültürün dişavurumuyla gerçekleştirilmektedir. Özetle müzik öğrenilirken aynı zamanda kültür de öğrenilmekte ve bu da davranışa yansımaktadır. Bu bağlamda düğün ezgilerinin eğlenceli yapısı içerisinde hüzünlü bir bölüm olan gelin almaçıkarma havaları, dramatik bir olayın öğrenilmiş bir davranışının müzikal ifadesidir. Müzisyeni bu ezgileri çalmaya zorlayan da olayın kendisidir ve müzisyen tarafından olay, müziğe koşulmaktadır.

Müziğin öğrenme davranışının topluluk üzerindeki işlevi ise ortaya çıkan müziğin ne anlam ifade ettiği ve dinlenilince verilecek tepkinin biçimidir. Bu bağlamda bir folklor icrası sırasında dinlenilen/duyulan bir ezginin türünden ve yapısal özelliklerinden kişinin veya topluluğun nasıl bir davranış şekli belirleyeceği anlamlandırma esasına göre gerçekleştirilir.

S. Davies, müzikal bir olayın belirli bir kültür içerisinde anlaşılmasına/anlamlandırılmasına yönelik şunları belirtmiştir (Davies, 1994 'ten aktaran: Şenel, 2014, s. 881):

1. Bir müzikal olayın diğerini neden takip ettiğine ilişkin bir hissiyat

2. Hangi müzikal olayın geleceğini öngörebilmek

3. Bir müzik parçasının bittiğini hissedebilmek

4. Tekrarlayan öğeleri tanımak

5. Bir parçanın bölümleri arasındaki benzerlik ve farklılıkları anlamak

6. Başka parçalar arasındaki benzerlik ve farklılıkları anlamak

7. Kendi müzikal arka planına dayanan beklentileri yabancı müzik türüne uygulamamak Müziğin yerel karakterine işaret eden ve yerel kültür çerçevesinde anlaşıldığını belirten bu yaklaşım kültürel görecelilik içinde değerlendirilebilir. Kültürün anlaşılmasında bağlam merkezli bir yaklaşıma dayanan bu maddeler, bir folklor unsuru olarak müziğin anlam bağlamının (context of meaning) ve durumsal bağlamının (situational context) ne olduğunun çözümlenmesine dayanmaktadır. 
Gelin alayının davul zurna eşliğinde güle oynaya kız evine gelmesiyle beraber gelin almaçıkarma havaları ile müzikal yapının değişmesi, kültürel zeminde icra edilen folklor olaylarının sıralanışının karşılıklı iletişim ve etkileşimi temelinde durumsal bağlamın değişimine örnek oluşturmaktadır. Aynı zamanda buradaki folklor olayının (gelinin, baba evine veda töreni) anlam bağlamının kültür içerisinde bilinmesiyle gelin alma-çıkarma havalarının icra edilmesi bir müzikal olayın diğerini neden takip ettiğine ilişkin bir hissiyat ve hangi müzikal olayın geleceğini öngörebilme ile ortaya çıkmaktadır. Bu doğrultuda ritüellerle yüklü bir geleneksel tören içerisinde belirli sıraya göre oluşturulan ve icra edilen folklor olaylarında bir müzik parçasının biteceği ve yerine başkasının başlayacağı hissedilebilir ve hatta bilinebilir. Örneğin 5/8'lik bir ölçüye sahip bir melodi kalıbının bir cenk havası olabileceği çıkarılabilir. Yine davula tokmak ve çırpı aracılığıyla gerçekleştirilen ritim yapılarından ezginin türü bilinebilir; icracının verdiği mesaj anlaşılabilir. ${ }^{*}$ Bu noktada müzik, kültürün öğrenilmiş bir davranışı olarak dinleyenlerin topluma karşı konumlanmasını sağlamaktadır.

Düğün törenlerinin müzikal açıdan son bölümünü "gelin indirme havaları" oluşturmaktadır. Geleneksel düğünlerde gelinin at ile oğlan evine getirilişiyle başlayan bu süreçte fetihten başarıyla dönülmüştür. Kazanılmış bir zafer, elde edilmiş bir ganimet vardır. Bu doğrultuda artan coşkuyla orantılı olarak müzikal yapı hareketlenmekte ve müziğe dans eşlik etmektedir. Türk kültüründe oğlan evine getirilen gelinin "özenklik, inmelik, indirmelik" (Töret, 2013, s. 44) gibi adlar altında arabadan inmesini sağlayacak hediye ritüelleri hemen her yörede görülebilmektedir. Müzik ise bu noktada, hediye ritüeline katılacak şekilde müzisyenin fiziksel, sosyal, öğrenme gibi çeşitli müzik davranışı biçimleriyle kendini yineler. Örneğin davulcu ve zurnacı, gelini indirmeme kervanına katılarak indirmelikten payını almak için fiziksel ve sosyal müzik davranışı biçimlerinde bulunur. Davulcunun bahşiş için yol kesmesi, tokmağını daha sık ve güçlü vurması fiziksel davranışa; toplumun kültür yapısına uygun bir şekilde davranması gerektiği ve kendisinden beklenen eylemleri gerçekleştirmesi ise sosyal davranışa örnek oluşturmaktadır. Aynı zamanda bu, öğrenme davranışıdır. Geleneğin kültür içerisindeki bir evrede ne olacağı, nasıl davranılacağı, nasıl karşılanacağı bilinmektedir.

Müzikal açıdan bu evrenin diğer bir özelliği ise gelinin attan (araçtan) inerken "gelin övmesi” olarak bilinen türkülerin söylenmesidir. (Yeşil, 2012, s. 217). Müziğin tekrar sözlü bir davranış olarak kendini gösterdiği bu bölümde -örneğin Adana yöresinde- "Giydiğin hara gelinim/ İnme pınara gelinim/ Allah onara gelinim/ Sen sefa geldin gelinim/ (Ağzın tatlı olsun);

\footnotetext{
* Örneğin Osmanlı ordusunun gün boyu süren savaşlarında o günkü çarpışmaların bittiğinin "tabl-1 âsâyiş", kalenin fethedildiğinin veya zaferin kazanıldı̆̆ının "tabl-1 beşâret" yahut "kûs-1 müjde" vuruşlarıyla duyurulması. (https://islamansiklopedisi.org.tr/davul).
} 
Giydiğin çizme gelinim/ Koncunu büzme gelinim/ Komşuyu gezme gelinim/ Sen sefa geldin gelinim..." (Başçetinçelik, 2009, s. 8) şeklinde sözler içeren türkülerle kutlama, kutsama, öğütleme yapılır. Diğer taraftan müzik, artık olay örgüsü çerçevesinde müzisyenin fiziksel bir davranışı olarak hareketlenir ve toplumu hareketlendirir.

\section{Sonuçlar}

Jeef T. Titon'a göre (2009) müzik, "dünyadaki hayata özel bir insan uyarlamasıdır; her müzik kültürü de belirli durumlara özgü bir adaptasyondur” (s. 123). Müziğin bağlamsal şartlara göre oluştuğunu ve şekillendiğini anlatan bu yaklaşımın bir örneğini düğünler oluşturmaktadır. Düğün geleneğinin başlangıcından sonuna kadar zengin ritüellerden biri olan müzik, olay örgülerinin birbirine bağlı kültürel halkaları içerisinde yaratılmakta ve biçimlenmektedir. Alan Merriam'ın "bir davranış biçimi olarak” tanımladığı ve çözümlediği müziğin en geniş kültürel kodlarla yer bulduğu düğün törenleri çerçevesine şunları söyleyebiliriz:

Müzik, bir (kültürel) olayın davranışı olarak ortaya çıkmaktadır. Davranış biçimi olarak yansıyan/yansıtılan müzikten hareketle tekrar davranışs şekilleri oluşmaktadır. Yani müziğin insanların davranışlarını belirlemesi ve yönlendirmesi söz konusudur. Görüleceği üzere olaydan hareketle müzik davranışı kadar müzikten hareketle de insan davranışı meydana gelmektedir. Müziğin fiziksel bir davranış olarak çoğu uygulamaları aslında, müziğin sözsüz bir iletişim biçimi olarak işlevde bulunduğunun göstergesidir. Örneğin bahşiş almak için gerçekleştirilen çalgıcının hareketleri ve bunun anlamlandırılması, müzik yoluyla kurulan bir kültüre özgü sözsüz iletişim biçimidir. Burada müzisyenin fiziksel davranışı yoluyla kültürü anlama/ anlamlandırma söz konusudur. Bununla beraber müzik, yine sözsüz iletişim biçimi olarak kullanılmak istendiğinde ezgisel sembolik anlamlar kümesi şeklinde kendini gösterir. Bir toplumda kültürel aşamalardaki ritüellerden biri olan veya ritüele eşlik eden müzik, olay örgülerinin davranışının bir göstergesi olarak toplumun üyeleri tarafından anlaş1ır, anlamlandırılır ve anlatılır. Böylelikle bir kültür içerisindeki törenlerde farklı karakterler içeren olayların anlamları birleştirilerek kültürel yapı tamamlanır.

\section{Kaynaklar}

Ataman, S. Y. (1992). Eski Türk Düğünleri ve Evlenme Ritleri. Ankara: Kültür Bakanlığı.

Attali, J. (2014). Gürültüden Müziğe, (Gülüş Gülcügil Türkmen, Çev.), İstanbul: Ayrıntı Yayınları.

Başçetinçelik, A. (2009). Adana Düğünlerinde Gelin İndirme. http://turkoloji.cu.edu.tr/HALK BILIM/aysebascetincelik_gelin_indirme.pdf. [Erişim: 08.05.2019.]

Boratav, P. N. (1982). Folklor ve Edebiyat II. İstanbul: Adam Yayınları.

Çelik, S. (2017). Türk Kültüründe Geçmişten Günümüze Davul. İnsan ve Toplum Bilimleri Araştırmaları Dergisi. 6, (8), 11-18. 
Çobanoğlu, Ö. (2005). Halkbilimi Kuramları ve Araştırma Yöntemleri Tarihine Giriş. Ankara: Akçağ Yayınları.

Davies, S. (1994). Musical Meaning And Expression, New York: Cornell University Press.

Öğüt Eker, G. (1998). Karakeçili Türk Düğünü. Doktora Tezi. Hacettepe Üniversitesi, Ankara.

Öğüt Eker, G. (2000). Türk Düğün Geleneği İçinde Karakeçili Türk Düğününün Ritüel Açıdan Değerlendirilmesi. Milli Folklor, 12, (46). 92-100.

Elschekova, A. (1997). Functions and Transformational Processes of Central European Wedding Songs. The World of Music, 39, (3), 31-50.

Görkem, İ. (2001). Türk Edebiyatında Ağıtlar- Çukurova Ağıtları. Ankara: Akçağ Yayınları.

Lomax, A. (1968). Folk Song Style and Culture. Washington D.C. American Association fort he Advancement Of Science Publication.

Merriam, A. (1964). The Anthropology Of Music. Northwestern University Press.

Mirzaoğlu, G. (2015). Halk Türküleri: Konu-İcra-Yapı-Anlam-İ̧şlev. Ankara: Akçağ Yayınları.

Örnek, S. V. (1995). Türk Halkbilimi. Ankara: Kültür Bakanlığı.

Özdemir, N. (2005). Cumhuriyet Dönemi Türk Eğlence Kültürü. Ankara: Akçağ Yayınları.

Şenel, O. (2014). Müziğin Evrenselliği Varsayımı ve Etnomüzikolojide Evrensel Arayışı. Uluslararası Sosyal Araştırmalar Dergisi, 7, (33), 872-889.

Titon, J. T. (2009). Music and Sustainability: An Ecological Viewpoint. The World of Music, 51, (1), 119-137.

Töret, A. B. (2013). Yapısal ve İşlevsel Özellikleriyle Gelin Göçürme: Muğla İli Örneği. TÜBAR, $34,35-56$.

Yeşil, Y. (2012). Türk Dünyasında Geçiş Dönemi Ritüelleri ve Bu Ritüellerde İcra Edilen Türler. Doktora Tezi, Gazi Üniversitesi Sosyal Bilimler Enstitüsü, Ankara. 